\title{
Application of Interdisciplinary Theory of Genres in LIS
}

\author{
Marek Nahotko \\ ORCID 0000-0002-4823-8080 \\ Institute of Information Studies, Faculty of Management and Social Communication, \\ Jagiellonian University in Kraków, Poland
}

\begin{abstract}
Purpose/Thesis: The article presents the possibilities of using the interdisciplinary theory of genres, developed in the study of linguistics, literary studies, rhetoric, sociology, philosophy, psychology and other disciplines, in library and information science (LIS). The article argues the application of genre theory to LIS offers a new and interesting interdisciplinary perspective.

Approach/Methods: A critical analysis of the literature on the subject introduces the basic premises of the interdisciplinary theory of text/information genres in its historical development in the world and in Poland. A similar method was used to present the most important directions genre theory opens to LIS. Results and conclusions: Before genre theory was first applied to LIS, it was developed in disciplines such as linguistics, literature, rhetoric, communication and media, discourse analysis, sociology, pedagogy and others and in many countries on all continents (mainly in the USA, Australia, Brazil and Scandinavian countries). The theory's success is a result of its interdisciplinary development, beginning from linguistic and classical rhetorical genres approach and problems of categorizing texts to "de facto genres" and their function in everyday communication activities (social/rhetoric approach). Applied to LIS, it frames information objects as social constructs whose meaning is constructed in social discourse, driven by genre knowledge. The library and other information systems should be treated as a social communication activity in the recurrent situation of organizing and retrieving information. It means that the work of a librarian (or other information organizers) involves rhetorical activity of creating information objects, as does the work of other information creators, e.g. authors of scholarly publications. The functioning of information system, i.e. production and organization of textual information should be investigated using methods applied in other disciplines, especially humanities and social sciences, as it allows for a broader research perspective.

Originality/Value: The article describes the possibilities of applying genre theory in LIS research, which still do not receive the attention they merit. A wider knowledge of the genre theory would make possible collaborative research involving scholars of other disciplines such as linguistics and sociology.
\end{abstract}

\section{Keywords}

Genre theory. Genre studies. Interdisciplinary research. LIS interdisciplinarity. LIS theories.

Received: 28 May 2020. Reviewed: 30 June 2020. Accepted: 28 August 2020.

\section{Introduction}

Although all scientific knowledge might be divided into disciplines, the boundaries between them are not clearly defined, and, as time passes they even blur. This is caused by, among others, frequent scientific collaboration between disciplines, valued and supported in the world of science (Chang, 2018, 1589). Library and Information Science (LIS), as a discipline 
with information as its main research interest ${ }^{1}$, has always interacted with other disciplines concerned with information (Beghtol, 1995, 30), and it is difficult to find a discipline that has no whatsoever connection with the subject however differently understood. Hence, Beghtol's pursuit of a resolution to the contradiction - information as a single object of study, subject to multiple disciplinary treatment - which she believed she found in interdisciplinarity: a way to establish connections between all factors shaping the modern world, incorporating approaches of LIS as a scientific discipline. Therefore, the more scientific institutions and information needs to become specialized, the more necessary is the mutual exchange of thoughts and stimulation to solve current scientific problems. Therefore, paradoxically the more certain issues and research practices become common, the more useful becomes an in-depth specialization will be.

This collaboration and interaction, very common in LIS scholarship ${ }^{2}$, gave rise to conviction of the "natural interdisciplinarity" of the discipline, widely shared by the scholars (Prebor, 2010; Saracevic, 1999, 1052). Holland claims $(2008,9)$ that the main feature of interdisciplinarity is the integration of methods and problems from various disciplines. He proposes a definition of interdisciplinary research as requiring integration of knowledge and/or methods of different disciplines to solve common problems. According to OECD report (Apostel et al., 1972, 25) this interaction may range from simple communication of ideas to mutual integration of organizing concepts, methodology, procedures, epistemology, terminology, data, and organization of research and education in a fairly large field. Therefore, LIS assimilates parts of other disciplines, their ideas, methods and functions as integrated elements of research (Holmes, 1999). Because the interactions of LIS with other disciplines occur constantly and are constantly changing, the level and functioning of LIS as an interdisciplinary discipline is also constantly changing (Zins, 2007). This situation is illustrated by, among others, the inconsistency across various discipline classifications, where LIS is considered as belonging to arts and humanities as well as to social sciences, communication and media, business/management, computer science, to name the most common. This makes manifest the heterogeneity of the discipline with a great variety of alliances (Nolin \& Åström, 2010, 9).

Interdisciplinary interactions between LIS and other disciplines are dynamic, inspirational and constructive (Tabatabaei \& Beheshti, 2008). LIS researchers need to acquire ideas and knowledge from other disciplines, ensuring that they will built on their achievements; their research and their own achievements must influence the results of other disciplines. The highly interdisciplinary nature of LIS positively distinguishes it from other disciplines, because, as Weinberg $(1963,166)$ wrote, this field has the highest scientific value, which most influences the achievements of neighboring scientific disciplines.

According to Urbano and Ardanuy (2020), the term "interdisciplinary" is used in the LIS literature as a general concept covering two basic situations: cooperation in publishing

\footnotetext{
${ }^{1}$ For the purpose of this paper LIS is understood according to Hjørland's definition $(2019,169)$ : a study of human interaction with the universe of recorded knowledge. We will understand recorded knowledge as information.

2 The extent of the interaction is discussed in studies on the citation of works by specialists outside LIS by LIS researchers and vice versa. There are many more of the former (Pluzhenskaya, 2008). A high proportion of non-LIS articles in LIS journals was also noted, which confirms that LIS is substantially affected by other disciplines (Chang, 2018).
} 
(within the same journal titles without co-authorship, or through co-authorship) and LIS researchers' reception of methodological and epistemological influences from other disciplines. In this article we will mainly deal with the latter. Interdisciplinary research offers special benefits such as quick and effective problem solving when it is possible to find and apply the right theor $y^{3}$ from another discipline. This practice also allows the development of discipline-specific theories, methods and principles. The integration of theories developed in other disciplines supports methodological development; it also creates challenges and opportunities by linking LIS with dynamic and promising research areas emerging in other disciplines. As a result, well-conducted interdisciplinary research prevents the stagnation of LIS theoretical framework by integrating fresh research questions explored in other disciplines. Collaborative research conducted by groups of scientists from different disciplines, employing their theories to achieve a common goal can be continued in LIS after integration with its own theories, tools and research methods (Rogers et al., 2003, 3).

LIS research often employs tools of other disciplines; theory of genres might become another such tool. It could be particularly beneficial as genre theory is as inherently interdisciplinary as LIS itself. The theory offers interesting research methods and perspective to LIS. In their interdisciplinarity both genre theory and LIS base on the achievements of similar scientific disciplines. This makes genre theory easily implemented in LIS studies. The purpose of the article is to explore the possibilities of using theory of genres, created and developed on the basis of scientific disciplines such as linguistics, literary studies, rhetoric, sociology, philosophy and psychology, in LIS research. Both LIS and genre theory center information contained in texts, utterances and messages, conditioning and orienting social activities of communicating parties. Hence, the application of this theory in LIS has many benefits, as it directly concerns the discipline's main research subject. It provides a new perspective on social rhetorical activities related to the organization of information in information systems.

The next part of the article will discuss genre theory in more detail. Firstly, it will present the theory as interdisciplinary. The activities and achievements of major centers in the world in which this theory is developed will be briefly summarized. Secondly, it will introduce the possibilities of using genre theory in LIS studies. Such a research practice, based on the achievements of another discipline, allows a new perspective on information and knowledge organization processes.

\section{Interdisciplinary theory of information genres}

All human activities are accompanied by communication processes that depend on many factors, including the communication technologies they use. In oral cultures information and knowledge were communicated with songs, stories, and sagas. Literate cultures have introduced new tools, depending on the technologies used for recording and transmitting information: manuscript, print, digital. Changing forms and means of communication are an inherent part of every culture, as they structure and sustain all social activities. The

${ }^{3}$ The term "theory" is defined here, after Smiraglia (2002), as a system of testable explanatory statements derived from research. 
concept, which covers the entirety of information communication forms that support purposeful human interaction, is that of genre.

Genre theory is actually a family of theories employed in theoretical study of information and information-related activities located in social practices (Andersen, 2006; Kjellberg, 2009). Over the past forty years, scholars working in many disciplines have revolutionized our understanding of genres. They have departed from the original idea that genres are simple categories of text types. Instead, they began to treat genres as a combination of differentiated forms of information materialization and forms of social activities. As a result of this research, genres were increasingly defined as a way to recognize and support the reproduction of recurrent situation and to construct responses to it, like a sensible behavior of the situation participants. Treating genres as typized ways of interacting participants of recurrent ${ }^{4}$ situations, initiated by Carolyn Miller (1984), had a major impact on the development of genre theory. Several research centers were established for genre theory development on almost all continents (mainly in the USA, Australia, Brazil, France, Denmark, Switzerland), in which genres were studied by scholars of various disciplines (linguistics, literature, rhetoric, communication and media, discourse analysis, sociology, pedagogy and others ${ }^{5}$ ) and in various contexts (including scientific and professional publishing and knowledge organization). In this way, centers (schools) of research on genres were emerged, which shaped the modern understanding of the concept.

Representatives of abovementioned and other disciplines discussed genre from various research perspectives. This is why they wrote about genres of text, speech, utterance or document (Nahotko, 2018, 129). In my opinion, what all their arguments have in common is the role of information in communication processes. In current rhetoric genre theory, which I will discuss in more detail below, the most important feature of a genre is its communication purpose, achieved through the information transfer. The other features of the genre, such as the form of the message (textual: manuscript, print, electronic etc.), are of secondary importance. Genre is an important tool for locating and organizing forms of information in indexing and accessing archives (Geisler et al., 2001, 278). Genre defines information used in people's communicative activity and their understanding of it. Without the orientation genre provides, we would not know where to look for information or what that information might mean. It means that genre knowledge relates to the information contained in the message, and that its form is matched to communication purpose, achieved by information transfer. For this reason, in the article I use the term information genre as a catch-all generic term.

Such a strong level of interdisciplinarity and geographical dispersion of research made difficult an agreement on an unambiguous definition of term "genre". There are two competing theories of genre: those that treat it as a kind of text (information carrier) and those that treat it as a classification system. This ambiguity stems from the question of whether genres are treated as tools for sorting and classifying experiences, events and activities that they represent (when they are considered a kind of labels or containers for meaning), or

\footnotetext{
4 Recurrence is closely related to variation, so genres must be able to adapt to such variation; as Bazerman writes $(2012,265)$, a conceptual challenge may require a disruption of the genre.

5 The disciplines listed here mainly use the concept of genre to analyze textual information. Equally extensive theories of genres are offered by disciplines concerned with other forms, such as film and fine arts, and, recently, Internet, combining all previously existing forms and creating its own.
} 
whether they reflect, help to shape, and even create what they represent in a way defined by culture, which would explain why they play an essential role in creating meanings. Genres, therefore, form a set of conventional and highly organized constraints on the creation and interpretation of meaning. In various periods and in different research areas, genre was defined and used mainly as a classification tool, a way to sort and organize materialized texts in documents and other information objects ${ }^{6}$. More recently, in many research disciplines, there has been an understanding of genres as powerful, ideologically active and historically modifiable tools for constructing information, meanings and social activity. From this point of view, genres are understood as a form of knowledge defining, mediating, understanding and performing a typical response to recurrent everyday situations. This view defines genres both as a creating and organizing types of information objects and related social activity in a complex, dynamic and mutual relationships (Bawarshi \& Reiff, 2010, 4).

Antunes, Costa and Pino (2006) claim that genres initially served as a way of organizing and classifying literary works, and that the texts were studied as belonging to a specific class of texts, distinguished on the basis of formal features. This allowed the scholars to show the organizing principles of literary creation. More recently, this theory has been used to identify and express the principles and conventions of creating and consuming information objects other than literary texts. This research centers genres of everyday private and professional activities, referred to as "de facto genres", which falls within the rhetorical tradition. Current theory of genres prioritizes the problems of current discourse over traditional disciplinary divisions, as evidenced by the wide range of discipline profiles of researches publishing on genre theory: they are representatives of the humanities, social, cognitive, linguistics and computer science, who all use their specific methodological approaches and theoretical frameworks to describe the nature and goals of genre forms (Trace \& Dillon, 2012, 509). Genres in everyday life, as well as within scientific disciplines and professional use are of particular interest to researchers. It is currently believed that genre structures exist within all communication situations, which means that most professional communities use genre structures in collaboration, often without formally expressing the fact. Even if it remains unarticulated, a large part of the education and socialization of professionals for their professional or research activities consists of their education in identifying, creating and applying socially accepted communication patterns used in cooperation with other members of their professional or scientific information world (Jaeger \& Burnett, 2010).

Luzón (2005) attempted to order the diverse approaches to information genres, distinguishing two traditions in the treatment of genres: linguistic and rhetorical ${ }^{7}$. There are further complementary empirical approaches to genre analysis which do not fall into the division she describes. Research in empirical direction was initiated by Yates and Orlikowski (1992), who analyzed genres in business organizations using historical analyzes supported by theory of structuration. Their work inspired further research in the field of information

6 The understanding of information object is borrowed from activity theory to examine the ways in which some groups of people coordinate their actions to achieve a common goal (Winsor, 2007, 3). An object of activity system is the problem, space, or focus of activity upon which the system acts. Objects of information activities are used to contain materialized information. Information object in information system is the object upon which people within the system act with during information activities.

7 Rhetoric is understood here as a symbolic action; it is the use of language as a symbolic tool to shape attitudes and encourage behaviors (Burke, 1951) by communicating information. 
systems using genre analysis. In particular, certain studies in the field of social sciences and cognitive science explored the use of documents in organizations and the design of their new electronic forms, which applied genre theory to everyday life situations to understand how information objects can not only reflect, but also influence the practices.

The linguistic approach focuses on linguistic analyzes of the text and its structure, and the results obtained are often used in models employed in education and efforts to improve literacy. According to researchers using this approach, spoken and written language plays a crucial role in socialization, preparing people to live in a community and to take meaningful actions in recurring situations (Halliday, 2003). The components of linguistic analysis are: text (the content of what is spoken or written), situation (the environment in which the text is created), register (semantic type of the text), code (controlling semantic styles available in a specific context), language system and social structure. Linguistic diversity is a result of the multiplicity of social contexts in which the language is used.

It is worth mentioning the Polish achievements of linguistic genology, which is an undeniably interdisciplinary discipline. It has been developing since the 1960s, when text became the center of linguists' attention, replacing syntax; text linguistics began to develop (Ostaszewska, 2008). Over time, this discipline has evolved to include the social context. The linguists turned to discourse - communication activities as socially and culturally conditioned verbal interactions. This brought on the development of discourse theory, based on psychology (psycholinguistics), cognitive sciences and other social sciences (e.g. sociolinguistics) in addition to linguistics. This allowed the scholars to track the phenomenon of verbal interaction in social, cultural and situational contexts. As a result of this interdisciplinary collaboration, linguistic genology developed, following the tradition of literary genological research and supported by discourse analysis (Furdal, 1982). An important development was the highlighting of the so-called utility (non-literary) genres. According to Ostaszewska $(2008,19)$, we can identify the following stages of linguistic genology's development:

- from a text treated as a finished product, a structured communication unit: text linguistics;

- through messages created by people in their natural environment: the theory of discourse;

- to the contemporary observation of genre heterogeneity: genology.

The study of genre within rhetoric is close to phenomenological and sociological traditions (Bawarshi \& Reiff, 2010). This approach is related to the rhetorical dimension of language use, social constructivism, rhetorical understanding of rationality and the theory of speech act as a mode of action. It emphasizes the relationship between the textual information and the broader social context in which the genre function. It requires understanding of the complex social, cultural, institutional and disciplinary factors affecting people when they create and recreate reality, learn (construct knowledge), and interact with language through different types of information objects. Genres influence the ways in which we experience, co-construct and perform social practices, and choose the places of activity. From this point of view, genres are considered to be relatively unstable or "stabilized for now" constructs, rhetorical forms that must be learned, taking into account the context of their use in relation to the purposes for which they are used by a particular discourse community (Swales, 1990, 21-32). These features result from their momentous role in the 
processes of structuration described by Giddens (2003), i.e. reproduction of social structures during their application. People live in a socially structured world, but at the same time, with the help of their social and cultural resources and activities, they co-construct social structures. This approach, which explores genres as forms of situational cognition, social activities, and social reproduction, does not focus as much on the precise linguistic analysis.

Such a dynamic view of genres requires organization of research which goes beyond genre's formal features. These features are treated as secondary, informed by social purposes of communication as well as the related ways of acquiring knowledge. The formal features of the message result from its purpose - which enables genres to perform specific social activities/relationships related to the specific situation in which they are used. Purpose is the most important genre attribute. The rise of a new communication purpose or a modification of an existing one results in the creation of a new or modification of an existing genre. In other words, genre knowledge consists not only of knowledge regarding the formal features of information and its objects, but mainly of the purposes which genres fulfill. Therefore, genres become a tool of orientation, allowing the user to orientate themselves in the meaning of communicated information, and thus in the purpose of the actions undertaken, which are accompanied by communication. Genres make it possible to negotiate intentions in relation to social motives and expectations of genres, to make decisions about the situations and reasons to use genres, to construct relationships between the information's sender and recipient, and to create relationships between genres during the coordination of social life manifestations.

In this tradition, genres are understood, as Miller suggested in her article cited above, as a form of social action. This paper follows this definition. It considers genre as social structure that mediates textual and social ways of constructing knowledge, existence and interaction in a specific context, which makes it a form of situated cognition. The context is very important here; understanding the context, its role in the uptake ${ }^{8}$, is both the beginning of the genre analysis and its purpose. In genre theory, information (e.g. textual) and context are not treated as separate categories; information is integrated into the context and action. Genres, as forming discourse or shaping communication strategies, provide flexible constraints or share tools necessary for the existence of an individual constructing reality in social context. Genres act as guides when people jointly and on an ongoing basis negotiate a common understanding of the situation and provide a measure of security allowing using communicated information in a predictable way (Schryer, 2002, $95)$. At the same time, Bazerman $(2009,290)$ emphasized that genres are a significantly socio-cognitive phenomenon. They are projections of meanings that allow orientation in mentally constructed shared spaces. They are also cognition tools, a part of the repertoire of cognitive practices comprising human sense-making. Understanding genres as a form of situational cognition, social action and social reproduction is a result of research of many disciplines that participated in the establishing of genre theory: rhetoric, sociology, phenomenology, philosophy, psychology, communication theory, semiotics, professional and scholarly communication (Bawarshi \& Reiff, 2010, 60).

\footnotetext{
${ }^{8}$ Uptake refers to the influence of a genre on the actions it causes (Freadman, 2002). It may, for example, indicate how so-called "calls for papers" produces an effect in the form of article proposals. In other words, it involves turning the act of illocution into perlocution.
} 
This "rhetorical turn" in the theory of genres caused a movement that is sometimes called sociologization of text and textual practices (Andersen, 2015c, 9). Giddens, mentioned above, contributed to the development of the theory; as did scholars of the philosophy of language building on (e.g. works of Wittgenstein and Austin), which prioritize the pragmatic aspect of language. Activity theory, developed by the Russian researchers of philosophy, pedagogy and psychology (such as Bakhtin, Vygotsky, and Luria) influenced Western researchers of genre theory. A common feature of all these disciplines and directions in the study of genres is the interest in, and special consideration of the conditions of human action as shaped by social structure. The concept of genre proposed by Miller and her successors fits perfectly into the relationship between human action and social structure, even if sometimes genre is considered as an action, sometimes as a social structure, and sometimes as an element serving mediation between people and social structures. In any case, genres are currently placed in a different theoretical space than in classical literary studies. Far from being merely "stylistic" devices, genres affect reality and truth, authority and acceptability, which are central to understanding the world in all research disciplines, arts, as well as in everyday life (Frow, 2015, 2).

\section{Genre theory in LIS research}

The preceding discussion of the development of views on genres in various disciplines suggests that in the contemporary understanding genre is viewed as a social action and as a tool of social organization, whose operation causes certain activities to recur in similar communication situations (Andersen 2004), where the situation is understood as a typical information structure. Because the organization of society can be described by the means and methods of communication known to its members, the creation, dissemination and use of information genres also depends on the system of activity, the abovementioned "uptake" of genres, which ensures that creation, dissemination and use of information will occur at a specific time and place, requiring such an organization of information, that will allow its retrieval. It follows that if theory of genres and their uptake is to allow a correct description of complex social interactions based on information transfer, its genres and social activities, including the creation and use of genres, then the results of LIS research, in particular in the field of information and knowledge organization, must contribute to the theory.

The organization of information and knowledge is therefore part of social organization in general. The organization of information materialized in information objects is a result of social efforts to self-define in communication processes using various tools and methods. Communication is understood here as a deliberate act in which information is intentionally used to change, shape or influence the state of affairs (situation). This definition is shared by representatives of social sciences, such as Jack Goody (2020) (anthropologist, developing literacy theory) and Jürgen Habermas (2015) (philosopher and social theorist), who highlight the role of writing and genres in the organization of societies. In several of his publications Goody showed how literacy affects social organization. He demonstrated for example how societies of Near East and Egypt and their organization were influenced by introduction and increasingly widespread use of writing in legal, political, religious, and trade activities. 
Habermas, on the other hand, introduced the concept of the public sphere. He described the splintering of the modern society into many spheres. The public sphere is developed to function as an intermediary connecting private realm and the sphere of public authority. In this sense the public sphere is treated as an organizational principle of social and political order. The theory explains how different kinds of information genres are developed and being used in the social and ideological organization of various spheres and areas in society (Andersen, 2006, 218). Public sphere is materialized in information genres used for social communication. Information genres and their communicative purposes in society determine the manner in which the user searches for information, contained in information objects. Therefore, seeking for information of particular genre means committing to particular forms of social organization. As Habermas's theory describes the role of various communication media in the organization and transformation of modern societies and the formation of public opinion, it can also be understood as the theory of the social organization of information objects and knowledge in society.

The various spheres: public, social and private, have different communication interests, and therefore they generate distinct ideas and conceptions, which are communicated through diverse information genres. Information objects are produced in the spheres, and their immanent feature is to act within and in-between the spheres, and therefore provide material basis for information communication actions. Information objects produced in every sphere are intended for wide public circulation, reception and critical discussion, which cause them to shift to the public sphere. Thus, theory of the public sphere accounts for the relationships between socially organized communication structures and the genres developed historically in those structures in response to the information needs and interests of various social spheres and domains. In effect, the theory reflects the organization of the producers, mediators, and users of information and its genres in society. Thus, it indicates existence of multiple information systems constructed in society. Therefore, it might be considered as a theory of the social organization of information in a form of genres and information objects.

Assuming that genres are typical rhetorical activities implemented in recurrent situations, rhetorical activity does not only have to be recognized (e.g. during cataloging, we determine the genre of the document being described), but that the organization of information is also a typical rhetorical activity. For example, the library, like any information system, facilitates specific rhetorical activities related to the organization and retrieval of information. All these activities require a creation of information, usually in the form of text. These activities fulfill the communication purposes of people functioning in context of the information retrieval, as a part of the social organization of this historically constructed information system. The resulting texts in appropriate information genre (e.g. bibliographic descriptions) are a part of social activities, facilitating their implementation and their reception allowing them for social participation. Information organization and retrieval are activities that support and transform social structures, to which the information users belong.

If we assume that the object of interest of LIS is (among others) the organization of information and knowledge materialized in information objects, then it becomes clear why theory of genres is a useful research tool (Andersen, 2008, 340). Genre studies reveal the important role of genre in connecting the organization of human activity to communicative activity. They point to individual and institutional preferences of genres in various communication situations and contexts. A look at such communication activities from the point 
of view of genre theory may inspire systematic study of the organization of information materialization into information objects and the subsequent use of these objects. It follows that the application of genre theory as an analytical tool in LIS allows us to understand the principles that govern communication at all levels of society's organization and the use of genres in the organization of activities (communication and others), information and people (their information worlds). Genre theory applies not only to people and the information they create, but also to their activities in typified, recurrent situations, in which they communicate information. An important aspect of these situations is information organization and retrieval, the domain of LIS.

Just as actions are recurrent, messages are standardized. Viewed through the lens of genre theory, the creation of information and information objects is not an isolated activity, but rather a part of more extensive social processes: information standardized by using genres is a part of all social activities. This results in the disciplinary diversity of genre structures, adapted to specific needs (e.g. geography - maps and atlases; law: codices, psychology: tests) (Hjørland, 2002, 437). The structure of a scientific article genre is also disciplinarily diversified. The organization of information, as a meta-action, takes into account these differences and enables these social activities. Therefore, information systems in which information is organized, structured with the help of such genres, should be treated as the basis for the functioning of all other social systems. Such an information system (e.g. archive, library, digital library, catalog, bibliography, but also search engine like Google) inheres in typical actions performed in recurrent situations of information needs. Therefore it is a genre created historically to support the writing and organization of information objects (Andersen, 2008, 360; Feinberg, 2015, 51). Genre knowledge of the users allows them to effectively distinguish between these (and other, non-listed) information genres (Geisler et al., 2001, 278).

Smiraglia (2002) showed the fundamental role of social sciences in the historical development of LIS' conceptual framework, in particular in the study of the organization of knowledge. The application of genre theory to LIS research, especially to knowledge organization creates the opportunity to form relationships with other theoretical discourses, mainly from social sciences. Genre theory also illuminates an important subject of LIS research. Theory of genres does not apply to information objects studied individually; rather, its purpose is to show that the fulfillment of a specific information need (manifest in both the creator and recipient of information) related to the use of information of a particular genre means the identification of a specific communication situation and the uptake of the genre in action. In social activities, so-called meta-genres, such as textbooks or regulations (e.g. cataloging rules) are used; they provide agreed genre knowledge about ways to create and negotiate genres and their uptake in the genres system that are in use (Bawarshi, 2016, 44).

It is important to note that a significant contribution of genre theory to LIS research is the departure from treating genre only as one of many characteristics of the information object contained in its bibliographic description (Crowston \& Kwasnik, 2003) to treating the genre as a typification of social activities related to the transmission of information in communication processes that resulting from the creation and use of materialized information by individuals in the society. This emphasis on information, its organization and participation in everyday social activities means that user studies in LIS can be treated as genre studies (Andersen, 2008, 348). 
Andersen (2008, 354) highlighted the following directions in LIS research where genre theory is (or should be) applied:

- The concept of genres as social action in LIS studies. The research concerns the means and methods of communication in the society of professional, scholarly, cultural and social knowledge materialized in information objects (printed and electronic). It also deals with the functions of information systems used to organize information and knowledge during the implementation of this communication processes. Genres, understood according to Miller's definition, are a tool for analyzing various communication practices. Where social activity is concerned, the information system, understood as a genre, must be seen from the perspective of the activities for which it is used and of the ways of mediating human activities in which it participates. The creator of the information system must define the ways in which its information resources will participate in other social activities (e.g. scientific research processes). In addition, genres research is closely related to information user research, as genre defines information needs. Similarly, genre can form the basis of research in knowledge organization.

- Genre and structuration theory in LIS studies. In the light of Giddens's theory, genres might be viewed as social institutions because they shape and are shaped by human communication activities. Genres represent both the social structure and the agent operating in it. As a result, genres simultaneously establish, regulate, create and reproduce social structures. The combined application of both theories (genre and structuration) allows scholars, for example, to describe the dynamics of the relationship between structure and agency in institutions (Yates \& Orlikowski, 1992). Knowledge is organized in the complex relationships between human activities, the media, genres, technologies, ideologies and institutional structures. The study of these relationships allows us to describe the ways in which knowledge and information organization influence social organization, genres and human activities. This locates research on the organization of information between both more general social theory and genre theory.

- Genre knowledge and its application in LIS research. Genre knowledge is a form of situational cognition (Bertenkotter \& Huckin, 1993). According to Austin (1993, 545), this means that, in order for the acts of locution and illocution (e.g. a scientific article or bibliographic description) to become a perlocutionary (influence, citations, etc. or effective information retrieval), communicators need to know how to use their understanding of genre. Genre knowledge allows the communicators to act properly in a particular (recurrent) communication situation that requires a typical response. In the area of LIS this means that an understanding of the sense of the situation, which forces information-seeking activities, is the condition of effective information retrieval. This also applies to the organization of information. The selection of information objects for cataloging and the way they are cataloged results from the level of genre knowledge of the cataloger. This reveals the cataloger's view of the document and its possible uses, which also allows the cataloger to determine the degree to which the goals and policy of the institution employing them are implemented. The information user's genre knowledge also allows for effective search for information (the correct use of the results of the information system's operation). 
- Genre systems in LIS research. Genres usually appear in groups and remain in relationships with each other. Research on the coexistence of related genres in a given situation helps to understand ways of organizing communication activities by using information materialized in documents. In LIS, such an understanding of genre-related practices (e.g. Nahotko, 2018) contextualizes activities related to the organization of information in information systems. In this way the information system is treated as a genre system, where a number of genres is used during organizational, professional practices.

- Genre and user studies. From the point of view of genre theory, information users can be perceived as sense-makers capable of designing and performing actions. This allows us to understand how the genre may be used alongside other tools and other tools to achieve our information goals in action. The user is shaped by language, genre and goal-oriented action. Therefore, they are seen in the context of complex interactions with other users, tools and activities used, typical and managed by genres in which all these elements interact with each other (Andersen, 2015b, 29). It also makes possible the contextualization of user activities leading to satisfaction of information needs with particular information genre.

The applications of genre theory are many and varied because genre uptake may result from the context of activities outside the genre, since genres always act as mediators between local and global levels (Andersen, 2017, 5). For example, the genre of bibliographic description mediates between its local cataloging context and the global, multi-domain context of information retrieval and development of domain knowledge. In this way, genres coordinate these social activities.

We can explore some of the possibilities of the use of rhetorical information genre theory on an example of six articles published in Genre Theory in Information Studies (2015), edited by Jack Andersen. This book gathers the results of research in LIS based on information genre theory. The authors of subsequent parts of the book have positions at departments of media or information studies in Canada, the USA, the Netherlands, and Denmark.

In the first text, Andersen (2015c) explains how genre theory approaches textual information and their corresponding social actions. While rhetorical genre theory had its beginnings in the humanities, it turned towards social sciences at the beginning of 1980s, which gave the theory its explanatory power. The theory was employed in LIS fields centering textual information and its social and communicative effects (Andersen, 2015a, xiv).

The second text, of the same author (Andersen, 2015b) proposes of a re-description of knowledge organization area based on genre and activity theories. In his opinion knowledge organization requires a new description in order to account for activities and practices constituting and causing concrete knowledge organization tasks. Genre theory was used as a framework for situating such a re-description.

The next author, Melanie Feinberg (2015) offers a new view of information systems. She argues that information systems can function as places for manipulation of genre resources, but without the purposeful actions of information objects' authors. Feinberg introduces the notion of "writerless" actions, undertaken by people responsible for organizing information in information systems based on appropriate rules and standards. These actions may result in genre modifications just as the purposeful actions of specific writers do.

The other areas of LIS explored with the reference to genre theory are information seeking and information management. Pamela McKenzie (2015) examines these two areas 
by means of genre theory. She has chosen two areas of practice: information seeking and distribution in clinical settings and personal information management in the household. Both case studies allow her to present possibilities of implementing genre approach to remove the dichotomy between workplace and everyday life information activities, usually existing in LIS research. As McKenzie argues, genre theory allows for approach focused on contexts of information activities.

Heather MacNeil (2015) also used a case study, focusing on a particular archival genre of finding aid, i.e. the calendar. She demonstrated how genre theory deepens and extends our understanding of archival finding aids as socio-cultural texts in contrast to the traditional approach which treats them as neutral tools used for facilitating access to archival resources.

Fiorella Foscarini (2015) has taken her case study from the archives too, although her paper is more theoretical. She commented on the limitations of the notion of organizational record used before. Using genre theory, she discovered that genre approach may help to both expand the scope of genre implementation area and to provide records management with new and more sophisticated tools to explore how records are made, used and transmitted in the workplace.

Laura Skouvig (2015), the author of the last chapter mentioned here, discusses information network in a specific chosen city (Copenhagen). Skouvig argues that, looking at different genres and genre systems, we can understand the ways of informing different groups of the town citizens. It shows how information develops in different genres, belonging to particular genre system, forming information network. Skouvig explains the dialogic nature of genres, information and the social world: genres shape and form information and thus affect their context.

The entire collection shows the possibilities of applying genre theory in LIS. It is an example of LIS interdisciplinary research on genre in information development, organization and use context which raises new questions and offers directions for further study (Andersen, 2015a).

\section{Conclusion}

The article discussed the possibilities of using interdisciplinary theory of information genres in LIS research. For this purpose it presented the interdisciplinary potential of the theory itself and the areas of LIS related to typified communication activities in recurrent situations of information organization and retrieval. Theory of genres furthered the field's development as it expanded the understanding of genre beyond the strictly linguistic and classical definition employed in the study of rhetoric, prioritizing the problems of categorizing texts to "de facto genres" and their function in everyday information communication activities. In LIS, this change is manifested in the shift of interest from genres traditionally treated as one of the attributes of information objects to treating information processes and information organization as a recurrent communication situations controlled by complex systems of information genres.

The application of the achievements of social constructivist theory in the field of LIS genre studies reframes information objects as social constructs whose meaning is constructed in social discourse, driven by genre knowledge. Genres are not neutral forms; rather they 
reflect the epistemological norms of discourse community that can be analyzed, discussed and questioned (Hjørland, 2002, 438). Research conducted with a reference to thus understood genre gives a better understanding of the organization of information in the theoretical context in which social activities and interactions that constitute information processes play the most important role. From this point of view, information organization both supports and constructs social activities and interactions.

The theory of genre is strongly situated in the humanities and social sciences, which also includes LIS. The application of genre theory in LIS frames users, information objects and systems as elements of social and cultural activities related to communication behaviors. Thus, LIS becomes an interdisciplinary field, capable of assimilating many perspectives developed in other disciplines. Interdisciplinary disciplines are naturally inclined to borrow perspectives from related disciplines. On the other hand, LIS studies should also provide their own contribution to genre theory, rather than rely on others' achievements. Such interdisciplinary cooperation will benefit LIS itself, as quantitative and qualitative research of genres used in different discourse communities (information worlds) may give rise to richer and more diverse information services.

\section{References}

Andersen, J. (2004). Analyzing the Role of Knowledge Organization in Scholarly Communication [online]. Royal School of Library and Information Science, [20.04.2020], https:/curis.ku.dk/ws/ files/47069480/jack_andersen_phd.pdf

Andersen, J. (2006). The Public Sphere and Discursive Activities: Information Literacy as Sociopolitical Skills. Journal of Documentation, 62(2), 213-228.

Andersen, J. (2008). The Concept of Genre in Information Studies. Annual Review of Information Science and Technology, 42(1), 339-367.

Andersen, J., ed. (2015). Genre Theory in Information Studies. Bingley: Emerald Publ.

Andersen, J. (2015a). Introduction. In: J. Andersen (ed.). Genre Theory in Information Studies (xiiixvi). Bingley: Emerald Publ.

Andersen, J. (2015b). Re-describing Knowledge Organization - a Genre and Activity-based View. In: J. Andersen (ed.). Genre Theory in Information Studies (13-42). Bingley: Emerald Publ.

Andersen, J. (2015c). What Genre Theory does. In: J. Andersen (ed.) Genre Theory in Information Studies (1-12). Bingley: Emerald Publ.

Andersen, J. (2017). Genre, Organized Knowledge, and Communicative Action in Digital Culture. In: J. Andersen \& L. Skouvig (eds.). The Organization of Knowledge: Caught Between Global and Local Meanings (1-16). Bingley: Emerald Publ.

Antunes, P., Costa C., Pino, J. (2006). The Use of Genre Analysis in the Design of Electronic Meeting Systems. Information Research, [online], 11(3), [19.04.2020], http://InformationR.net/ir/11-3/ paper251.html.

Apostel, L. et al. (1972). Interdisciplinarity: Problems of Teaching and Research in Universities. Paris: OECD.

Austin, J. (1993). Mówienie i poznanie. Rozprawy i wyktady filozoficzne. Warszawa: Wydaw. Naukowe PWN.

Bawarshi, A. (2016). Between Genres. Uptake, Memory, and US Public Discourse on Israel-Palestine. In: M. Reiff \& A. Bawarshi (eds.). Genre and the Performance of Publics (43-59). Boulder, CO: Univ. of Colorado Press.

Bawarshi, A., Reiff, M. (2010). Genre. An Introduction to History, Theory, Research, and Pedagogy. West Lafayette: Parlor Press. 
Bazerman, Ch. (2009). Genre and Cognitive Development: Beyond Writing to Learn. In: Ch. Bazerman, A. Bonini \& D. Figueiredo (eds.). Genre in a Changing World (283-298). Fort Collins, CO: Parlor Press. Bazerman, Ch. (2012). Writing with Concepts: Communal, Internalized, and Externalized. Mind, Culture, and Activity, 19(3), 259-272.

Beghtol, C. (1995). Within, Among, Between: Three Faces of Interdisciplinarity. Canadian Journal of Information and Library Science, 20(2), 30-41.

Burke, K. (1951). A Rhetoric of Motives. Berkeley, CA: Univ. of California Press.

Chang, Y. (2018). Examining Interdisciplinarity of Library and Information Science (LIS) Based on LIS Articles Contributed by non-LIS Authors. Scientometrics, 116(3), 1589-1613.

Crowston, K., Kwasnik, B. (2003). Can Document-Genre Metadata Improve Information Access to Large Digital Collections? Library Trends, 52(2), 345-361.

Feinberg, M. (2015). Genres without Writers: Information Systems and Distributed Authorship. In: J. Andersen (ed.). Genre Theory in Information Studies (43-66). Bingley: Emerald.

Foscarini, F. (2015). Organizational Records as Genres: an Analysis of the "Documentary Reality" of Organizations from the Perspectives of Diplomatics, Records Management, and Rhetorical Genre Studies. In: J. Andersen (ed.). Genre Theory in Information Studies (115-132). Bingley: Emerald Publ.

Freadman, A. (2002). Uptake. In: R. Coe, L. Lingard \& T. Teslenko (eds.). The Rhetoric and Ideology of Genre: Strategies for Stability and Change (39-53). Cresskill, NJ: Hampton Univ. Press.

Frow, J. (2015). Genre. London, New York: Routledge.

Furdal, A. (1982). Genologia lingwistyczna. Biuletyn Polskiego Towarzystwa Językoznawczego, 39, 61-70.

Geisler, C. et al. (2001). IText: Future Directions for Research on the Relationship between Information Technology and Writing. Journal of Business and Technical Communication, 15(3), 269-308.

Giddens, A. (2003). Stanowienie społeczeństwa. Zarys teorii strukturacji. Warszawa: Zysk i S-ka.

Goody, J. (2020). Logika pisma a organizacja społeczeństwa. Warszawa: Wydaw. Uniw. Warszawskiego.

Habermas, J. (2015). Teoria działania komunikacyjnego. T. 1. Racjonalność dziatania a racjonalność społeczna. Warszawa: Wydaw. Naukowe PWN.

Halliday, M. (2003). Language as Social Semiotic. In: J. Maybin (ed.) Language and Literacy in Social Practice (23-43). Clevedon: Multilingual Matters.

Hjørland, B. (2002). Domain Analysis in Information Science. Eleven Approaches - Traditional as well as Innovative. Journal of Documentation, 58(4), 422-462.

Holland, G. (2008). Information Science: An Interdisciplinary Effort? Journal of Documentation, 64(1), 7-23.

Hjørland, B. (2019). The Foundation of Information Science: One World or Three? A Discussion of Gnoli (2018). Journal of Documentation, 75(1), 164-171.

Holmes, B. (1999). An Inquiry into the Domain of Information Science, with an Emphasis on Contributing Disciplines, 1973 to 1998: Preliminary Results. In: Information Science: where has it been, where is it going? (84-114). Proceedings of the Annual Conference of CAIS, June 9-11, 1999. Sherbrooke, Quebec: Université de Sherbrooke.

Jaeger, P., Burnett, G. (2010). Information Worlds: Social Context, Technology and Information Behavior in the Age of the Internet, New York, NY: Routledge.

Kjellberg, S. (2009). Scholarly Blogging Practice as Situated Genre: an Analytical Framework Based on Genre Theory. Information Research [online], 14(3), [19.04.2020], http://InformationR.net/ ir/14-3/paper410.html

Luzón, M. (2005). Genre Analysis in Technical Communication. IEEE Transactions on Professional Communication, 48(3), 285-295.

MacNeil, H. (2015). The Role of Calendars in Constructing a Community of Historical Workers in the Public Records Office of Great Britain ca. 1850s - 1950s. In: J. Andersen (ed.) Genre Theory in Information Studies (91-114). Bingley: Emerald Publishing. 
McKenzie, P. (2015). Genre and Typified Activities in Informing and Personal Information Management. In: J. Andersen (ed.) Genre Theory in Information Studies (67-90). Bingley: Emerald Publishing.

Miller, C. (1984). Genre as Social Action. Quarterly Journal of Speech, 70(2), 151-167.

Nahotko, M. (2018). Teoria gatunków w organizacji informacji. Podejście informatologiczne. Kraków: Wydaw. UJ.

Nolin, J., Åström, F. (2010). Turning Weakness into Strength: Strategies for Future LIS. Journal of Documentation, 66(1), 7-27.

Ostaszewska, D. (2008). Genologia Lingwistyczna jako subdyscyplina współczesnego językoznawstwa. W: D. Ostaszewska \& R. Cudak (red.). Polska genologia lingwistyczna (11-39). Warszawa: Wydaw. Naukowe PWN.

Pluzhenskaya, M. (2008). LIS and Other Knowledge Domains: Interdisciplinarity of LIS Scholars' Publications (Pilot Study). In: C. Guastavino \& J. Turner (eds.). Proc. of the 36th Annual Conference of the CAIS [online], Vancouver, Univ. of British Columbia, June 5-7, 2008 [27.04.2020], https:// doi.org/10.29173/cais127

Prebor, G. (2010). Analysis of the Interdisciplinary Nature of Library and Information Science. Journal of Librarianship and Information Science, 42(4), 256-267.

Rogers, Y., Scaife, M., Rizzo, A. (2003). Interdisciplinarity: an Emergent or Engineered Process? Cognitive Science Research paper 556. Brighton: Univ. of Sussex.

Saracevic, T. (1999). Information Science. Journal of the American Society for Information Science and Technology, 50(12), 1051-1063.

Schryer, C. (2002). Genre and Power: a Chronotopic Analysis. In: R. Coe, L. Lingrad \& T. Teslenko (eds.). The Rhetoric and Ideology of Genre: Strategies for Stability and Change (73-102). Cresskill, NY: Hampton Press.

Skouvig, L. (2015). Genres of War: Informing a City. In: J. Andersen (ed.). Genre Theory in Information Studies (133-154). Bingley: Emerald Publishing.

Smiraglia, R. (2002). The Progress of Theory in Knowledge Organization. Library Trends, 50(3), 330-349.

Swales, J. (1990). Genre Analysis. English in Academic and Research Settings. Cambridge: Cambridge Univ. Press.

Tabatabaei, N., Beheshti, J. (2008). Interdisciplinary Outreach of Library and Information Science as Reflected in "Essential Science Indicators". In: C. Guastavino \& J. Turner (eds.). Proc. of the 36th Annual Conference of the CAIS [online], Vancouver, Univ. of British Columbia, June 5-7, 2008 [27.04.2020], https://doi.org/10.29173/cais133

Trace, C., Dillon, A. (2012). The Evolution of the Finding Aid in the United States: from Physical to Digital Document Genre. Archival Science, 12(4), 501-519.

Urbano, C., Ardanuy, J. (2020). Cross-disciplinary Collaboration Versus Coexistence in LIS Serials: Analysis of Authorship Affiliations in Four European Countries. Scientometrics [online], April, [24.04.2020], https://doi.org/10.1007/s11192-020-03471-z

Weinberg, A. (1963). Criteria for Scientific Choice. Minerva, 1(2), 159-171.

Winsor, D. (2007). Using Texts to Manage Continuity and Change in an Activity System. In: M. Zachry \& Ch. Thralls (eds.). Communicative Practices in Workplaces and the Professions. Cultural Perspectives on the Regulation of Discourse and Organizations (3-19). Amityville, NY: Baywood Publ. Company.

Yates, J., Orlikowski, W. (1992). Genres of Organizational Communication: a Structural Approach to Studying Communication and Media. Academy of Management Review, 17(2), 299-326.

Zins, Ch. (2007). Conceptions of Information Science. Journal of the Association for Information Science and Technology, 58(3), 335-350. 


\title{
Zastosowanie interdyscyplinarnej teorii gatunków w badaniach informatologicznych
}

\begin{abstract}
Abstrakt
Cel/Teza: Celem artykułu jest przedstawienie możliwości zastosowania interdyscyplinarnej teorii gatunków, tworzonej i rozwijanej przez uczonych wielu dyscyplin, między innymi w badaniach informacji naukowej (informatologii). Tezą autora jest możliwość zastosowania teorii gatunków w informatologii, co powinno otworzyć nowe i interesujące, interdyscyplinarne perspektywy badawcze. Koncepcja/Metody badań: Zastosowano metodę krytycznej analizy literatury przedmiotu w celu omówienia podstawowych założeń interdyscyplinarnej teorii gatunków tekstu/informacji w jej rozwoju historycznym na świecie i w Polsce. Z zastosowaniem podobnej metody przedstawione zostały także najważniejsze kierunki zastosowań teorii gatunków w informatologii.

Wyniki i wnioski: Zanim teoria gatunków znalazła zastosowanie w informatologii, była ona rozwijana w wielu innych dziedzinach i dyscyplinach, takich jak: językoznawstwo, literaturoznawstwo, retoryka, komunikacja i media, analiza dyskursu, socjologia, pedagogika i innych oraz w wielu krajach na wszystkich kontynentach (głównie w USA, Australii, Brazylii i krajach skandynawskich). Sukces tej teorii, stosowanej w badaniach wielu dyscyplin, wynika z kierunków jej interdyscyplinarnego rozwoju, poczynając od klasycznych teorii językoznawczych i retoryki, w których stosowana była do badania zagadnień związanych z kategoryzacją tekstów, aż po tzw. gatunki „de facto” i ich funkcje w codziennych działaniach komunikacyjnych (podejście socjologiczne/retoryczne). Jej zastosowanie w badaniach informatologii powoduje, że obiekty informacyjne rozumiane są jako konstrukty społeczne, których znaczenie jest konstruowane w dyskursie społecznym, w oparciu o wiedzę gatunkową społeczności użytkowników gatunku. Biblioteka, podobnie jak każdy system informacyjny, może być uważana za środowisko społecznej aktywności komunikacyjnej, realizowanej w powtarzalnych sytuacjach organizacji i wyszukiwania informacji. Oznacza to, że aktywność zawodowa bibliotekarza (lub innego pracownika informacji) polega na działaniach retorycznych, służących tworzeniu obiektów informacyjnych, w takim samym stopniu, jak innych twórców informacji, np. autorów publikacji naukowych. Funkcjonowanie systemu informacyjnego, służące tworzeniu i organizacji informacji tekstowej, powinno być badane $\mathrm{z}$ wykorzystaniem metod stosowanych i typowych dla innych dyscyplin, głównie społecznych i humanistycznych, ponieważ dają one szerszą perspektywę badawczą. Oryginalność/Wartość poznawcza: W artykule opisano nadal niedostatecznie znane możliwości zastosowania teorii gatunków w badaniach informatologicznych, szczególnie z punktu widzenia możliwości współpracy naukowej z przedstawicielami innych dyscyplin, takich jak językoznawstwo i socjologia.
\end{abstract}

\section{Słowa kluczowe}

Badania interdyscyplinarne. Genologia. Interdyscyplinarność informatologii. Teoria gatunków. Teorie informatologii.

Dr habil. MAREK NAHOTKO is an Associate Professor at the Jagiellonian University, Institute of Information Studies. He earned his PhD in bibliology at the University of Wroctaw, Poland, and habilitation in bibliology and informatology at the Warsaw University, Poland. He is specialized in problems of information and knowledge organization, especially electronic document metadata, and in the use of the Internet and electronic documents in scholarly communication and information processes. His most important publications include books: Teoria gatunków w organizacji informacji i wiedzy [Genre theory in information and knowledge organization] (Kraków, 2018), Komunikacja naukowa w środowisku cyfrowym [Scholarly communication in electronic environment] (Warszawa, 2010), Naukowe czasopisma elektroniczne [Scholarly electronic journals] (Warszawa, 2007), Opis dokumentów elektronicznych. Teoretyczny model i możliwości jego aplikacji [Electronic documents description. Theoretical model and possibilities of its 
application] (Kraków, 2006), Metadane. Sposób na uporządkowanie Internetu. [Metadata. A way to organize the Internet] (Kraków, 2004).

Contact to the Author:

marek.nahotko@uj.edu.pl

Institute of Information Studies,

Faculty of Management and Social Communication

Jagiellonian University

S. Łojasiewicza 4,

30-348, Kraków, Poland 